AKUNTANSI: Jurnal Akuntansi Integratif

Vol.6 No. 2 Tahun 2020

p-ISSN 2502-5376 e-ISSN 2715-0658

\title{
PENGUKURAN LABA BERDASARKAN PRAKTIK AKUNTANSI UMKM ONLINE DI KABUPATEN PAMEKASAN
}

\author{
Fena Ulfa Aulia ${ }^{1}$ \\ Indah Kuratul Aini ${ }^{2}$
}

\author{
Institut Agama Islam Negeri Madura ${ }^{1,2}$ \\ E-mail:_enaulfa@iainmadura.ac.id 1, indahkuratulaini31@gmail.com²
}

\begin{abstract}
ABSTRAK
Suatu entitas bisnis sejatinya harus terpisah dari entitas pribadi untuk dapat diukur kinerjanya. UMKM di Pamekasan sebagian besar masih belum memisahkan entitas pribadi dan bisnisnya sehingga pengukuran laba menjadi bias. Dewasa ini para pelaku UMKM di Pamekasan telah memanfaatkan sarana online dalam penjualannya baik melalui online shop maupun sosial media. Jika mengacu pada lahirnya akuntansi, praktik akuntansi lahir dari adanya praktik bisnis, sehingga dengan berubahnya praktik bisnis konvensional ke online juga mengubah praktik akuntansinya.Penelitian ini merupakan penelitian deskriptif kualitatif dengan menggunakan data primer melalui teknik wawancara terhadap koresponden dengan teknik analisis data mendeskripsikan data dan dibahas berdasarkan teori yang ada kemudian ditarik kesimpulannya. Populasi dalam penelitian ini merupakan semua UMKM online di Pamekasan dengan teknik pengambilan sampel secara random dengan memperhatikan prinsip kemudahan sebanyak 10 sampel. Hasil penelitian ini menunjukkan bahwa terdapat pengukuran laba UMKM online bervariatif dengan praktik akuntansi yang variatif dan masih sederhana serta belum mengacu pada SAK EMKM.
\end{abstract}

Kata kunci: Pengukuran Laba, Praktik Akuntansi, UMKM

\section{ABSTRACT}

A business entity must be separate from the private entity in order to measure its performance. Most of the UMKMs in Pamekasan have not yet separated their personal and business entities, so the measurement of earnings is biased. Nowadays, the SMEs in Pamekasan have utilized online facilities in their sales both through online shops and social media. When referring to the birth of accounting, accounting practices are born from business practices, so that changing conventional business practices online also changes accounting practices. This research is a qualitative descriptive study using primary data through interviewing correspondents with data analysis techniques describing data and discussed based on existing theories then conclusions are drawn. The population in this study is all online MSMEs in Pamekasan with random sampling techniques with regard to the principle of convenience as many as 10 samples. The results of this study indicate that there are various online MSME earnings measurements with varied accounting practices and are still simple and do not yet refer to SAK EMKM.

Keywords: Profit Measurement, Accounting Practices, MSME 
Fena Ulfa Aulia, Indah Kuratul Aini / Pengukuran Laba Berdasarkan Praktik Akuntansi UMKM Online di Kabupaten Pamekasan 


\section{Pendahuluan}

Pemekasan merupakan salah satu kabupaten yang berada di Pulau Madura. Kabupaten Pamekasan memiliki luas wilayah 79.230 Ha yang terdiri dari 13 kecamatan dan 189 desa dengan jumlah penduduk 818.662 jiwa. Berdasarkan potensi penduduk yang ada di Pamekasan, membuat Pemerintah Kabupaten Pamekasan memanfaatkan sumber daya manusia yang melimpah agar produktif sehingga menghasilkan barang atau jasa yang bisa memberikan kontribusi bagi pendapatan daerah. Sebagai salah satu bentuk perhatian pemanfaatan sumberdaya manusia, Pemkab Pamekasan sudah melakukan pelatihan kewirausahaan yang sering diadakan oleh dinas terkait guna mewujudkan pemberdayagunaan sumber daya manusia dalam menyejahterakan ekonomi masyarakat Pamekasan. Pengembangan potensi daerah merupakan salah satu perhatian khusus Pemkab Pamekasan sebagai upaya penguatan ekonomi daerah.

Kabupaten Pemekasan merupakan wilayah daratan karena secara garis besar Kabupaten Pamekasan terdiri dari daratan rendah di bagian selatan dan daratan tinggi di bagian utara. Perkembangan Kabupaten Pamekasan tidak dapat dilepaskan dari potensi industri yang ada baik industri rumahan maupun industri yang sudah memiliki pabrik. Potensi industri merupakan penyumbang pendapatan tersendiri bagi kemajuan Kabupaten Pamekasan. Industri di Pamekasan memiliki hasil berkualitas tinggi hal ini dapat dibuktikan dengan dikenalnya hasil indutsri Pamekasan di luar daerah. Kondisi tersebut menjadikan Pamekasan dikenal oleh masyarakat luar sebagai daerah yang berpotensi industri inggi. Selain itu Kabupaten Pamekasan memiliki potensi lain yang memberikan kontribusi bagi pendapatan dan pengembangan daerah lokal seperti di bidang pariwisata, pertanian dan perkebunan. Hasil industri yang ada di Pamekasan bahkan menembus pasar internasinoal dan prestasi yang dihasilkan bidang industri tidak dapat dipisahkan dari peran UMKM yang ada.

UMKM (Usaha Mikro Kecil dan Menengah) merupakan pelaku ekonomi yang dapat di ibaratkan sebagai pioner suatu bangsa yang mampu menjelma sebagai dewa penyelamat bagi suatu bangsa, karena UMKM mampu bertahan dalam kondisi apapun baik dalam kondisi krisis ekonomi, UMKM mampu bertahan dan menyelamatkan perekonomian suatu negara (Aliyah, 2014). Pertumbuhan dan perkembangan UMKM bisa dikaitkan dengan keberhasilan daerah yang memiliki pendapatan rendah. Hal ini berarti UMKM bisa mengurangi angka kemiskinan karena mampu menyeimbangi kondisi ekonomi suatu negara baik dalam keadaan ekonomi stabil maupun dalam keadaan krisis. Dengan demikian peran UMKM perlu ditingkatkan agar mampu bersaing dan menerapkan pengelolaan mananjemen bisnis yang baik. Di satu sisi UMKM mengalami keterlambatan dalam perkembangannya dibandingkan perusahaan karena menghadapi berbagai masalah seperti masalah pembiayaan, pemasaran dan kualitas SDM (Wibowo dkk., 2015). Keberadaan UMKM dinilai mampu menyerap tenaga kerja sehingga dapat mengurangi tingkat pengangguran.

Peran UMKM dalam suatu negara tidak dapat dipisahkan karena di setiap negara dari masing-masing daerah turut menyumbangkan peran UMKM dalam menyerap tenaga kerja dan memberikan kontribusi pendapatan bagi masing-masing wilayah. Wilayah yang menjadi penyumbang kontribusi pendapatan daerah yakni Kabupaten Pamekasan. Usaha mikro kecil menengah yang ada di Kabupaten Pamekasan memiliki potensi besar yang dibuktikan dengan data jumlah UMKM menurut Dinas Koperasi dan UKM Provinsi Jawa Timur melalui Sensus Ekonomi 2016 dan SUTAS 2018, yaitu sebanyak 247.369. Bidang nonpertanian menempati jumlah UMKM sebanyak 108.722 dan di bidang pertanian dan 138.547. Hal tersebut membuktikan bahwa partisipasi masyarakat Pamekasan dalam mengembangkan jiwa wirausaha sangat tinggi. Jumlah UMKM setiap tahunnya diprediksi akan naik karena didukung oleh dinas terkait yang melakukan pelatihan untuk memulai dan mengembangkan usaha. Keberadaan UMKM di Kabupaten Pamekasan masih dikategorikan menggunakan 
perlakuan bisnis tradisional dibandingkan perusahaan pada umumnya yang sudah memiliki pangsa pasar tersendiri.

Sebagian besar praktik bisnis yang diterapkan UMKM di Kabupaten Pamekasan masih sangat sederhana karena pengendalian manajemen dari kegiatan usaha hanya dikendalikan oleh pemilik usaha saja sedangkan karyawan hanya mengerjakan instruksi dari pemilik. Bisnis yang dijalankan setiap UMKM di Kabupaten Pamekasan tidak memperhatikan aspek fungsional perusahaan yang meliputi manajemen keuangan, manajemen produksi, manajemen sumber daya manusia dan manajemen pemasaran sehingga unsur-unsur sistem pengendalian manajemen yang meliputi perencanaan strategi, pembuatan anggaran, alokasi sumber daya, pengukuran, evaluasi, dan penghargaan atas kinerja, alokasi pusat tanggung jawab, dan penepatan harga transfer yang dijalankan oleh UMKM tidak jelas, karena pada dasarnya UMKM di Kabupaten Pamekasan tidak menerapkan unsur-unsur sistem pengendalian manajemen dengan baik. Praktik bisnis yang sederhana pada UMKM menyebabkan pencatatan dari setiap anggaran dan pendapatan yang diperoleh tidak ada batasan antara aset pribadi dan asset usaha, sehingga perlakuan akuntansi pada UMKM tidak sesuai prinsip akuntansi keuangan yang dapat diterima secara umum maupun SAK EMKM.

Pada umumnya saat ini praktik bisnis di Indonesia telah menggunakan sosial media dan online shop sebagai salah satu bentuk pemasaran selain menggunakan iklan. Penggunaan sosial media dan online shop sebagai alat promosi dapat mengurangi biaya iklan yang harus ditanggung oleh perusahaan. Selain dapat melakukan efisiensi biaya, penggunaan sosial media dan sarana online shop yang ada saat ini dianggap sebagai langkah efektif karena hampir semua orang telah menggunakan sarana digital dalam kehidupan sehari-harinya. Tidak jauh berbeda, sebagian besar UMKM di Pamekasan juga telah menggunakan sosial media sebagai alat promosi dan ada beberapa UMKM yang sudah memanfaatkan online shop. Penggunaan sosial media sebagai alat promosi telah menjadi kebutuhan bagi para pelaku UMKM di Pamekasan saat ini. Praktik bisnis UMKM dengan menggunakan sosial media dan online shop telah merubah praktik bisnis konvensional di mana pembeli harus bertemu penjual serta membayar di tempat atau transfer kepada penjual. Namun dengan penggunaan sosial media dan online shop, pembeli tidak harus bertemu dengan penjual di tempat yang sama melainkan dapat mengorder barang yang dibutuhkan melalui chat pribadi kepada penjual dengan cara pembayaran yang telah disepakati bersama. Perubahan praktik bisnis UMKM di Pamekasan saat ini sedikit banyak juga dapat berdampak pada praktik akuntansi. Dalam sejarah perkembangannya, pencatatan transaksi sudah dimulai sejak manusia memulai kegiatan ekonomi, pertukaran maupun kerja sama (Harahap, 2018). Hal tersebut dapat dimaknai bahwa, setiap praktik ekonomi akan diikuti oleh praktik pencatatannya (akuntansinya) sehingga perkembangan bentuk bisnis seharusnya juga diikuti dengan perkembangan pencatatannya. Praktik bisnis via online dan media sosial yang ada merupakan suatu perkembangan praktik bisnis dari jual beli offline. Perkembangan praktik bisnis ini seharusnya juga diikuti dengan perkembangan akuntansinya.

Akuntansi konsep kesatuan ekonomi (economic entity concept) merupakan konsep yang menyatakan bahwa aktivitas perusahaan harus dipisahkan secara jelas dari pemilikinya dan dari kesatuan usaha lainnya. Konsep ini diharapkan dapat membantu UMKM untuk mengetahui laba usaha yang dicapai. Konsep kesatuan usaha tidak akan berjalan dengan baik jika UMKM tidak memperhatikan perlakuan akuntansinya, sehingga banyak pelaku usaha UMKM menyatakan bahwa dalam usahanya laba dapat ditentukan tanpa menggunakan pelaporan keuangan atau mengikuti kaidah standar akuntansi keuangan untuk Entitas Mikro Kecil Menengah (EMKM). Padahal jika ditelusuri lebih dalam, laba yang diperoleh UMKM masih tercampur dengan entitas pribadi.

Berdasarkan latar belakang di atas penulis termotivasi mengangkat sebuah judul 
tentang "Pengukuran Laba Berdasarkan Praktik Akuntansi UMKM Online Di Kabupaten Pamekasan". Adapun masalah dalam penelitian ini, yaitu bagaimana praktik akuntansi serta pengukuran laba yang dilakukan oleh para pelaku UMKM di Pamekasan dengan menggunakan sosial media. Mengacu pada masalah yang telah diuraikan, adapun tujuan yang ingin dicapai dalam penelitian ini, yaitu untuk mengetahui praktik akuntansi serta pengukuran laba UMKM dengan menggunakan sosial media di Pamekasan.

\section{Kajian Pustaka}

Akuntansi

Eksistensi suatu entitas dapat diukur melalui kegiatan transksi-transaksi yang telah dilakukan. Transaksi suatu entitas harus dicatat secara detail dengan tujuan untuk mengetahui setiap pendapatan yang diperoleh dari biaya yang dikeluarkan perusahaan dalam menghasilkan barang atau jasa. Sehingga diperlukan pencatatan dari setiap transkasi yang dikenal dengan akuntansi. Menurut A statement of Basic Accounting Theory (ASOBAT) akuntansi adalah sebuah proses mendefinisikan, mengukur, dan memberikan informasi ekonomi sebagai acuan dalam hal pengambilan keputusan. Sedangkan menurut Syafri Harahap (2007) akuntansi merupakan suatu singkatan apabila dijabarkan menjadi angak-angka yang menjadi dasar pengambilan keputusan, yang berkaitan dengan uang dan nilai moneter yang menggambarkan transaksi perusahaan. Selain itu dapat di analisis lebih lanjut dan bersifat netral untuk semua pihak, dan ada unsur seninya serta merupakan informasi yang sangat diperlukan dengan tujuan pengambilan keputusan (Syakur, 2015). Jadi dapat di simpulkan bahwa akuntansi adalah proses mengindentifikasi transaksi-transaksi entitas yang berupa angka-angka dimana angka tersebut memberikan informasi dalam pengambilan keputusan. Akuntansi sangat diperlukan bagi pihak intern dan ekstern selaku pengguna informasi akuntansi.

Pengguna informasi akuntansi diantaranya pertama pihak intern yakni manajemen yang membutuhkan informasi keuangan dalam rangka perkembangan perusahaan. Kedua pihak ekstern yakni investor, investor selaku pemegang saham membetuhkan informasi akuntansi untuk mengetahui perkembangan dari modal yang ditanamkan pada suatu perusahaan. Kreditor merupakan pengguna akuntansi yang bertujuan untuk menilai kemampuan perusahaan dalam memenuhi liabilitisnya. Supplier dan distributor merupakan pengguna informasi akuntansi karena melalui laporan keuangan supplier mampu mengetahui sejauh mana perusahaan harga barang yang sudah disuplai. Sedangkan bagi distributor informasi akuntansi berguna untuk mengukur kelangsungan perusahaan dalam barang yang didistribusikan. Serikat kerja merupakan pengguna informasi akuntansi dengan tujuan untuk mengetahui posisi pekerja terkait hubungan kerja dengan perusahaan. Pencari kerja merupakan pengguna informasi akuntansi karena melalui informasi keuangan perusahaan pencari kerja dapat mengestimasikan kemampuan perusahaan dalam membayar jasanya dan atas kelangsungan pekerjaan dikemudian hari. Pemerintah merupakan pengguna informasi akuntansi karena melalui catatan keuangan perusahaan dapat menentukan pajak, statistik ekonomi dan membuat kebijakan di sektor ekonomi dan kesejahteraan publik (Syakur, 2015). Akuntansi sebagai sistem informasi yang menyediakan laporan keuangan harus memenuhi karakteristiknya supaya berguna bagi pemakai laporan keuangan.

Adapun karakteristik laporan keuangan yakni dapat dipahami, relavan dan dapat dibandingkan (Baridwan, 2004). Laporan keuangan adalah hasil dari proses akuntansi yang dapat digunakan sebagai alat untuk membandingkan antara data keuangan atau aktivitas suatu perusahaan dengan pihak yang berkepentingan dengan data atau aktivitas perusahaan tersebut. Laporan keungan disusun dan disajikan sekurang-kurangnya setahun sekali untuk memenuhi kebutuhan sejumlah besar pemakai(Santoyo 2013). Untuk memenuhi tujuannya 
laporan keuangan menggambarkan pertanggungjawaban manajemen dalam mengelola sumber daya yang telah dipercayakan oleh investor kepadanya. Posisi keuangan suatu entitas terdiri dari aktiva dan pasiva pada suatu periode tertentu (Hutagaol 2012). Laporan keuangan terdiri dari beberapa unsur seperti pertama posisi keuangan suatu perusahaan yang memuat aktiva, kewajiban dan modal. Kedua laporan keuangan yang berkaitan dengan pengukuran kinerja perusahaan yang lebih dikenal laporan laba-rugi adalah pendapatan dan beban. Ketiga laporan perubahan ekuitas dan laporan perubahan kas yang menggambarkan berbagai unsur laporan keuangan. Perubahan tersebut disebabkan oleh transaksi-transaksi operasional dan nonoperasional (Syakur 2015).

Praktik Akuntansi

Praktik akuntansi pada umumnya dilaksanakan berdasarkan siklus akuntansi. Akuntansi sebagai aktivitas perolehan jasa keuangan maka perlu melewati tahapan-tahapan proses data yang meliputi aktivitas-aktivitas pembuatan dokumen transaksi, pencatatan transaksi, pengelompokan data, pengikhtisaran data dan pengolahan data. Tahapan data itulah disebut siklus akuntansi yang terjadi selama satu periode. Entitas dalam mengimplementasikan praktik akuntansi berdasarkan akuntansi yang dapat diterima umum (Syakur, 2015). Dalam praktik akuntansi, terdapat asumsi konsep entitas dimana perusahaan harus memisahkan antara harta pribadi dengan harta perusahaan dengan tujuan untuk mempermudah pegukuran laba yang diperoleh. Selain itu praktik akuntansi memuat asumsi konsep kelangsungan usaha yang merupakan dasar mengapa akuntansi mengukur asset berdasarkan nilai perolehan historis serta asumsi unit moneter yang stabil artinya perusahaan hanya mencatat data transaksi yang dinyatakan dalam satuan uang (Jusup, 2011). Tetapi dari asumsi-asumsi yang ada dalam praktik akuntansi yang sudah diterapkan entitas pada umumnya berbeda dengan perlakuan akuntansi yang diterapkan UMKM.

Pengukuran Laba

Pada dasarnya setiap entitas wajib membuat laporan keuangan termasuk UMKM. Perilaku Herding yaitu kecenderungan meniru tindakan dari orang lain sangat cocok bagi UMKM untuk membuat laporan keuangan. Karena melalui perilaku herding oleh pelaku UMKM dapat ditunjukkan dengan membuat catatan keuangan apabila ada pelaku UMKM membuat catatan keuangan maka UMKM lain akan mngikutinya (Andhika dan Damayanti, 2017). Catatan keuangan setiap kegiatan usaha pada dasarnya sangat dibutuhkan karena hal tersebut akan mempengaruhi laba operasional sebuah usaha. Laba menurut IAI adalah kenaikan manfaat ekonomi selama suatu periode akuntansi dalam bentuk masukan atau penambahan aktiva atau penurunan liabilitas yang mengakibatkan kenaikan ekuitas yang tidak berasal dari kontribusi penanaman modal. Sementara itu menurut Fisher (1912) dan Bedford (1965) menyebutkan tiga konsep laba yang umum digunakan dalam ekonomi. Konsep laba tersebut adalah:

1) Phychic Income, yang menunjukkan konsumsi barang/jasa yang dapat memperoleh kepuasan dan kebutuhan individu.

2) Real Income, yang menggambarkan kenaikan dalam kemakmuran ekonomi yang ditunjukkan oleh kenaikan cost of living.

3) Money Income, yang menggambarkan kenaikan nilai moneter dan sumber-sumber ekonomi yang digunakan untuk konsumsi sesuai dengan biaya hidup (Ghozali dan Chariri, 2014). Oleh sebab itu diperlukan acuan pencatatan keuangan bagi UMKM dalam menyusun laporan keuangan. 
UMKM (Usaha Mikro Kecil Menengah)

Menurut Undang-undang No.20 Tahun 2008 usaha kecil merupakan usaha produktif dengan skala kecil dengan kriteria kekayaan bersih yang dimiliki maksimal Rp200.000.000 dan memiliki penjualan paling banyak sebesar Rp1.000.000.000. berdasarkan Undang-undang tersebut menyatakan bahwa usaha kecil menengah dalam pasal 1 yang menyatakan bahwa "usaha kecil adalah kegiatan ekonomi rakyat yang berskala kecil dan memenuhi kriteria kekayaan bersih atau hasil penjualan tahunan serta kepemilikan sebagai diatur dalam undang-undang"'(Savitri dan Saifudin, 2018). Adapun definisi usaha mikro kecil dan menengah Menurut Undang-undang No.20 tahun 2008 dirinci menjadi:

1) Usaha kecil adalah:

a. Usaha ekonomi produktif yan berdiri sendiri, dilakukan oleh perorangan atau badan usaha yang bukan merupakan anak perusahaan atau bukan cabang perusahaan yang dimiliki, dikuasai atau menjadi bagian baik langsung maupun tidak langsung dari usaha mengah atau usaha besar yang memenuhi kriteria usaha kecil.

b. Memiliki kekayaan bersih lebih dari Rp50.000.000, tidak termasuk tanah dan bangunan tetap usaha, atau memiliki hasil penjualan tahunan lebih dari Rp300.000.000 sampai dengan paling banyak Rp2.500.000.000.

2) Usaha menengah adalah:

a. Usaha ekonomi produktif yang berdiri sendiri, yang dilakukan oleh orang perorangan atau badan usaha yang bukan merupakan anak perusahaan atau bukan cabang perusahaan yang dimiliki, dikuasai, atau menjadi bagian baik langsung maupun tidak langsung dengan usaha kecil atau usaha besar.

b. Memiliki kekayaan bersih lebih dari Rp500.000.000 sampai dengan paling banyak Rp10.000.000.000 tidak termasuk tanah dan bangunan tempat usaha atau memiliki hasil penjualan tahunan lebih dari Rp2.500.000.000 sampai paling banyak Rp10.000.000.000 (Andasari dan Dura, 2018).

SAK EMKM (Standar Akuntansi Keuangan Entitas Mikro kecil dan Menengah)

Pencatatan keuangan oleh UMKM dapat direalisasikan beradasarkan acuan SAK EMKM (Standart Akuntansi Keuangan Entitas Mikro, Kecil dan Menengah). Tujuan laporan keuangan adalah untuk menyediakan informasi posisi keuangan dan kinerja suatu entitas yang bermanfaat bagi pihak berkepentingan. Posisi keuangan meliputi asset, liabilitas dan ekuitas. Pada SAK EMKM pengukuran dalam laporan keuangan tidak diperkenankan saling hapus antara asset dan liabilitas atau penghasilan dan beban kecuali diizinkan oleh SAK tersebut. Kepatuhan terhadap penggunaan ED SAK EMKM. Dimana entitas yang membuat laporan keuangannya berdasarkan ED SAK EMKM harus membuat pernyataan secara eksplisit dan tanpa terkecuali tentang kepatuhannya terhadap ED SAK EMKM tersebut. Laporan keuangan yang diisyaratkan untuk disusun adalah:

1) Laporan posisi keuangan pada akhir periode yang mencakup akun-akun kas dan setara kas, piutang, persediaan, asset tetap, utang usaha, utang bank dan ekuitas.

2) Laporan Laba Rugi selama periode yang mencakup akun-akun pendapatan, beban keuangan dan beban pajak.

3) Catatan atas alaporan keuangan yang memuat semua pernyataan bahwa laporan keuangan disusun berdasarkan ED SAK EMKM, ikhtisar kebijakan akuntansi dan informasi tambahan dan rincian akun tertentu yang mendeskripsiskan akun-akun penting sehingga bermanfaat bagi pengguna (Dewan Standar Akuntansi Keuangan, 2016)

Di samping pencatatan keuangan yang masih sederhana, UMKM mampu bersaing dalam pemasaran produk yang dihasilkan. Menurut kolter pemasaran merupakan proses 
manajerial yang mencakup individu dan kelompok dalam mendapatkana apa yang mereka butuhkan dan diinginkan dengan menciptakan penawaran dan menukarkan produk yang dihasilkan dengan pihak lain (Diniyanti dan Agusrinal, 2014). Pemasaran yang paling menguntungkan bagi UMKM yakni melalui media sosial.

Media Sosial dan Online Shop

Media sosial merupakan media yang menawarkan digitalsasi, convergence, interactivity, dan development of network terkait pembuatan pesan dan penyampaiannya. Media sosial mempunyai kemampuan interaktif dalam menawarkan pesan yang akan disampaikan memberikan pengguna dari media sosial untuk memilih informasi apa yang akan dikonsumsikan sekaligus memberikan pengendalian terhadap informasi yang dihasilkan dari media sosial (Watie, 2011). Mengutip dari Wikipedia "media sosial adalah sebuah media daring, dengan para penggunanya bisa dengan mudah berpartisispasi, berbagi dan menciptakan isi blog, jejraing sosial, wiki, from dan dunia virtual" (https://id.wikipedia.org/wiki/Media_Sosial ). Dewasa ini pemasaran atas produk melalui media sosial semakin banyak. Menurut Rangkuti pemasaran adalah kegiatan manusia untuk memuaskan kebutuhan dan keinginan melalui pertukaran. Jadi pemasaran melalui media sosial adalah kegiatan menawarkan barang/jasa dengan tujuan untuk memuaskan kebutuhan dan keinginan manusia melalui pertukaran (Suryani, 2014).

Online shop atau belanja online via internet, adalah suatu proses pembelian barang atau jasa dari penjual melalui internet atau layanan jual-beli secara online tanpa harus bertatap muka dengan penjual atau pihak pembeli secara langsung. Seiring dengan terjadinya perubahan perekonomian dan globalisasi, telah terjadi perubahan dalam perilaku berbelanja pada masyarakat. Perubahan dalam perilaku berbelanja pada masyarakat merupakan konsekuensi logis dari tuntutan kehidupan yang dipicu dengan adanya perkembangan teknologi komunikasi dan informasi. Pada awalnya penjualan barang dilakukan secara konvensional, yaitu antara penjual dan pembeli bertemu secara langsung untuk melakukan transaksi jual beli. Seiring dengan kemajuan teknologi internet penjualan bisa dilakukan secara online (Sari, 2015).

\section{Metode Penelitian}

Jenis Penelitian dan Teknik Sampling

Penelitian ini merupakan penelitian deskriptif kualitatif, yaitu penelitian kualitatif dengan mendeskripsikan kondisi objek penelitian. Populasi penelitian ini adalah semua pelaku UMKM yang pemasarannya menggunakan sosial media maupun online shop dengan teknik pengambilan sampel secara acak dengan memperhatikan prinsip kemudahan. Penelitian ini menggunakan entitas UMKM yang menggunakan sosial media dan online shop sebagai sarana promosi sebagai objek penelitian sebanyak 10 UMKM. Berikut ini merupakan daftar sampel yang digunakan dalam penelitian ini: 
Tabel 1

Daftar Sampel Penelitian

\begin{tabular}{|c|l|l|l|}
\hline $\begin{array}{c}\text { No } \\
.\end{array}$ & \multicolumn{1}{|c|}{ Nama UMKM } & $\begin{array}{c}\text { Nama Akun di Sosmed/ online } \\
\text { shop }\end{array}$ & \multicolumn{1}{|c|}{$\begin{array}{c}\text { Jenis Sosmed/ Online } \\
\text { shop }\end{array}$} \\
\hline 1. & Bakmi01 & Bakmi01 & Facebook \\
\hline 2. & Kopi Mangrove & Aisyahstore83 & Shopee \\
\hline 3. & $\begin{array}{l}\text { Oemah Butik } \\
\text { Rintauncha }\end{array}$ & Butik Rinta Uncha & Facebook \\
\hline 4. & Teri Crispy & Sumber Hasil & Facebook \\
\hline 5. & Buah Online & Retno Bakul Buah Pamekasan & Facebook \\
\hline 6. & $\begin{array}{l}\text { RJK Bordir dan } \\
\text { Konveksi }\end{array}$ & Onk Konveksi dan Bordir & Facebook \\
\hline 7. & Green Juice & Green Juice & Go Food \\
\hline 8. & Mida Busana & Hamidah Fahas/ Mida Busana & Facebook \\
\hline 9. & Batik Imada & $\begin{array}{l}\text { Batik Imada/ Rumah Batik } \\
\text { Imada }\end{array}$ & Facebook/ Instagram \\
\hline 10 & Teri Crispy Almund & Teri Crispy Almund & Instagram \\
\hline
\end{tabular}

Data dan Teknik Pengumpulan Data

Data yang digunakan dalam penelitian ini merupakan data primer dan data sekunder berupa informasi yang diperoleh langsung dari para pelaku UMKM dan hasil screenshoot sosial media UMKM yang dijadikan objek penelitian. Teknik pengumpulan data yang digunakan dalam penelitian ini dilakukan melalui wawancara dan dokumentasi.

Definisi Operasional dan Teknik Analisis Data

Variabel dalam penelitian ini terdiri dari dua variabel yaitu variabel praktik akuntansi (X) dan variabel laba (Y). Variabel praktik akuntansi dalam penelitian ini didefinisikan sebagai praktik pencatatan transaksi dan pelaporan keuangan UMKM. Sementara variabel laba didefinisikan sebagai laba operasional/ usaha.

Analisis data yang digunakan dalam penelitian ini yaitu dengan melakukan tabulasi data yang kemudian dideskripsikan dalam bentuk kata-kata dan ditarik kesimpulannya.

\section{Hasil}

Pengukuran laba UMKM online berdasarkan praktik akuntansi di Kabupaten Pamekasan berbeda-beda, satu dari sepuluh sampel yang ada laba diukur dengan cara pengestimasian; satu diantara sepuluh tidak ada pengukuran laba secara pasti namun diakui sebagai laba selama dapat memenuhi kebutuhan pribadi dan produksi; dua dari sepuluh sampel yang ada, laba diukur sebesar persentase tertentu dari omzet yang ada kemudian dikurangi oleh biaya produksi/ kulakan; enam dari sepuluh sampel yang ada, laba diukur sebesar selisih penjualan dengan pembelian barang dagangan/ biaya produksi. Berikut ini merupakan uraian singkat tentang pengukuran laba berdasarkan praktik akuntansi UMKM online di Kabupaten Pamekasan:

\section{a. Bakmi01}

Bakmi01 merupakan UMKM online yang berdiri sejak tahun 2017 dan berlokasi di Jalan Veteran Muda Nomor 01 Pamekasan. Usaha ini bergerak di bidang kuliner bakmi dengan toping yang variatif dibandingkan dengan bakmi lainnya yang ada di Pamekasan. Dalam menjalankan bisnisnya, usaha ini dioperasionalkan oleh satu orang saja dari semua fungsi organisasi yang ada. Praktik akuntansi yang dilakukan Bakmi01 ini dapat dikatakan sangat sederhana karena sebagian besar transaksi tidak dilakukan pencatatan 
namun hanya menggunakan estimasi saja. Pencatatan hanya dilakukan untuk transaksi pesanan dari pembeli atas order dari pembeli namun pembelian bahan dan biaya produksi tidak dicatat hanya perkiraan saja. Dalam usaha ini juga belum ada pemisahan antara entitas pribadi dan bisnisnya. Bakmi01 mengukur laba dengan cara menghitung selisih uang yang diterima dari penjualan dengan uang yang dikeluarkan untuk membeli bahan produksi. Dalam usaha ini juga belum disusun laporan keuangan.

b. Kopi Mangrove

Kopi Mangrove merupakan salah satu UMKM di Pamekasan yang memanfaatkan online shop sebagai sarana penjualan produknya. Bisnis ini dimulai sejak tahun 2014 berawal dari niat untuk melindungi hutang mangrove di daerah Talang Siring Pamekasan. Usaha ini berlokasi di daerah Candih Talang Kabupaten Pamekasan. Dalam mengoperasionalkan bisnisnya, pemilik merangkul organisasi Sabuk Hijau dalam memproduksi biji kopi mangrove. Namun dalam sisi manajemen bisnisnya hampir semua fungsi dikendalikan langsung oleh pemiliknya termasuk meracik kopi mangrove di bagian produksi. Dalam usaha ini tidak ada pencatatan transaksi baik pengeluaran maupun penerimaan uang sehingga dapat dikatakan praktik akuntansi dalam usaha ini tidak ada, namun demikian usaha ini masih mampu bertahan hingga saat ini. Pengukuran laba dalam usaha ini adalah melalui terpenuhinya kebutuhan pribadi dan produksi dari uang yang diterima dari penjualan yang ada. Usaha ini juga belum menyusun laporan keuangan dalam bentuk apapun

c. Oemah Butik Rinta Uncha

Oemah Butik Rinta Uncha merupakan UMKM yang memanfaatkan sosial media Facebook dan Whatsapp sebagai sarana promosi produknya. Usaha ini berdiri pada tahun 2016 dan berlokasi di Desa Cemara Kembar Pademawu Barat Kabupaten Pamekasan. Dalam menjalankan operasionalnya semua fungsi manajemen dilakukan dan dikendalikan sendiri oleh pemiliknya. Meskipun semua fungsi manajemen dan pengendaliannya dilakukan oleh pemiliknya sendiri namun dalam bisnis ini sudah terdapat pemisahan keuangan bisnis dan pribadi. Pencatatan transaksi yang dilakukan dalam bisnis ini masih sangat sederhana berupa pembelian dan penjualan barang dagangan. Pemilik butik ini juga sudah mengenal konsep harga perolehan dalam pembelian barang dagangan sehingga harga jual yang ditentukan diperoleh dari harga pembelian barang dagangan ditambah biaya pengiriman dan laba yang diharapkan sehingga laba diukur dari selisih harga jual dan harga pembelian barang dagangan ditambah biaya pengiriman. Laporan keuangan yang dibuat hanya berupa laporan laba-rugi sederhana sebatas pengetahuan pemilik tanpa adanya pengurangan beban periodik

d. Teri Crispy Sumber Hasil

Teri Crispy Sumber Hasil merupakan UMKM di Pamekasan yang memanfaatkan Facebook sebagai sarana penjualannya. Usaha ini didirikan sejak tahun 2016 yang berlokasi di Desa Padelegan Kecamatan Pademawu Pamekasan. Usaha ini dijalankan dengan beberapa karyawan, antara karyawan dan pemilik masih terdapat hubungan keluarga. Untuk bagian keuangan dikendalikan langsung oleh pemilik. Sementara marketing dilakukan oleh ponakan pemilik melalui sosial media dan offline. Bagian produksi dilakukan oleh pemilik dan beberapa karyawan yang ada. Praktik akuntansi yang dilakukan dalam usaha ini masih sangat sederhana, yaitu hanya berupa pencatatan pembelian bahan dan biaya produksi namun tidak demikian dengan transaksi penjualan. Laba diukur dengan cara uang yang diterima dari penjualan selama satu bulan dikurangi dengan biaya-biaya yang dikeluarkan. Laporan keuangan yang dibuat hanya berupa laporan laba rugi sederhana sebatas pengetahuan pemilik. 


\section{e. Buah Online}

Buah online merupakan UMKM di Pamekasan yang memanfaatkan Facebook dan Whatsapp dalam mempromosikan barang dagangannya. Tidak hanya menjual buah secara online, pemilik usaha ini juga melebarkan sayapnya dengan menjual salad buah dan minuman dari olahan susu secara online . Usaha buah online ini berdiri sejak tahun 2017 dan berlokasi di jalan Jokotole Pamekasan. Usaha ini dioperasionalkan oleh 5 orang saja, terdiri dari satu orang sebagai pemilik dan empat orang sebagai karyawan yang masih merupakan anggota keluarga sendiri. Satu orang bertugas melayani pembelian minuman dan salad; satu orang bertugas melayani pembelian buah dan dua orang bertugas meracik salad dan toping minuman. Pemilik berperan sebagai pengendali manajemen sekaligus pengelola keuangan dan racikan. Pencatatan transaksi yang dilakukan oleh pemilik hanya berupa pembelian buah, penjualan buah, produksi salad, pembelian bahan minuman dan penjualan minuman. Laba diukur dengan cara menghitung masing-masing selisih penjualan dan pembelian buah; penjualan dan biaya produksi (salad dan minuman). Laporan keuangan yang dibuat dalam usaha ini hanya berupa laporan laba rugi secara sederhana.

f. RJK Bordir dan Konveksi

RJK Bordir dan Konveksi merupakan salah satu UMKM di Pamekasan yang bergerak di bidang konveksi dengan memanfaatkan Facebook sebagai sarana promosi. Usaha ini dimulai sejak tahun 2015 dan berlokasi di Desa Bettet Pamekasan yang dipimpin oleh seorang direktur dan wakil direktur sekaligus pemilik (suami-istri). Dalam usaha ini sudah terdapat pemisahan fungsi dan tugas karyawan yang terdiri dari bagian produksi (pemotongan, penjahitan, dan bordir), bagian pemasaran dan bagian keuangan. Pencatatan transaksi pada usaha ini sedikit lebih kompleks dibandingkan UMKM lainnya dari sampel yang ada, pencatatan transaksi yang dilakukan dalam usaha ini meliputi pembelian bahan baku dan penolong, order dari pembeli, perolehan/ kinerja karyawan dan biaya overhead. Setiap hari dilakukan evaluasi hasil kerja bagian produksi dan setiap pekan dilakukan evaluasi bagian keuangan oleh direktur maupun wakil direktur. Meskipun demikian, laporan keuangan yang dibuat dalam usaha ini masih sederhana berupa laporan laba-rugi. Laba diukur sebesar selisih penjualan dikurangi biaya produksi tanpa dikurangi biaya periodik yang terjadi.

\section{g. Green Juice}

Usaha ini dimulai sejak tahun 2015 dan berlokasi di Jalan Niaga dan Jalan Kemuning. Terdiri dari 4 orang karyawan yang masing-masing berperan sebagai pembuat jus. Semua pengendalian manajemen dilakukan langsung oleh pemilik termasuk pencatatan transaksi dan pengelolaan keuangan. Meskipun menggunakan jasa go food, namun pencatatan transaksi masih manual dan sederhana berupa daftar pembelian bahan baku dan penolong, penjualan per hari dan pendapatan bersih per hari. Laba diukur setiap akhir bulan dengan cara menghitung selisih antara jumlah pendapatan bersih per hari selam satu bulan dan biaya periodik yang dikeluarkan.

h. Mida Busana

Usaha ini dimulai sejak tahun 2014 yang diawali sebagai agen baju ternama namun sejak 2016 Mida Busana telah memproduksi baju dengan brand sendiri dengan dibantu oleh 8 orang penjahit. Dalam usaha ini tidak ada pemisahan fungsi kecuali di bidang keuangan dikendalikan oleh pemilik langsung. Pencatatan transaksi masih sederhana berupa pembelian bahan, produksi dan penjualan. Laba diukur sebesar persentase tertentu dari omset kemudian dikurangi dengan biaya produksi.

i. Batik Imada

Usaha ini dimulai sejak tahun 2008 dan berlokasi di Jalan Jokotole (sebelah 
perpustakaan umum di Pamekasan). Batik Imada ini merupakan pengepul dari para pengrajin batik yang ada di Kabupaten Pamekasan, meski demikian ada kalanya Batik Imada mendesign sendiri batiknya namun pengerjaannya dilakukan oleh pengrajin batik. Pencatatan transaksi yang dilakukan masih sederhana meliputi transaksi pembelian batik ke pada pengrajin dan penjualan. Dalam usaha ini dilakukan pemisahan pencatatan antara penjualan offline dan online. Laba diukur sebesar persentase tertentu dari omset kemudian dikurangi dengan biaya produksi.

j. Teri Crispy Almund

Usaha ini dimulai sejak tahun 2014 berawal dari melimpahnya ikan teri di kawasan Desa Padelegan Pademawu dan berlokasi di Jalan Bonorogo. Terdapat 3 fungsi dalam usaha ini dan masih merupakan keluarga sendiri yang teriri dari founder sekaligus melaksanakan marketing; keuangan dan pembukuan (istri); serta bagian produksi yang dilakukan oleh kerabat terdekat pemilik. Pencatatan transaksi yang dilakukan berupa pembelian bahan baku, pelengkap dan penolong; biaya produksi dan penjualan. Laba diukur sebesar selisih penjualan dan harga pokok produksi tanpa adanya penghitungan biaya periodik. Berikut ini merupakan tabulasi data yang diperoleh dari hasil interview kepada narasumber.

Tabel 2

Tabulasi Data

\begin{tabular}{|c|c|c|c|}
\hline No. & $\begin{array}{c}\text { Nama Akun di Sosmed/ } \\
\text { online shop }\end{array}$ & Praktik Akuntansi & Pengukuran Laba \\
\hline 1. & Bakmi01 & $\begin{array}{l}\text { a. tidak ada pencatatan } \\
\text { transaksi namun hanya } \\
\text { menggunakan estimasi } \\
\text { saja } \\
\text { b. b. tidak ada pemisahan } \\
\text { entitas binis dan pribadi } \\
\text { c. c. belum menyusun } \\
\text { laporan keuangan } \\
\text { d. d. tidak mengenal SAK } \\
\text { ETAP }\end{array}$ & $\begin{array}{l}\text { Laba diukur sebesar selisih } \\
\text { penjualan dan biaya bahan } \\
\text { untuk produksi }\end{array}$ \\
\hline 2. & Aisyahstore 83 & $\begin{array}{l}\text { a. a. belum ada pencatatan } \\
\text { transaksi baik penerimaan } \\
\text { maupun pengeluaran kas. } \\
\text { b. b. belum menyusun } \\
\text { laporan keuangan } \\
\text { c. c. belum ada pemisahan } \\
\text { entitas bisnis dan pribadi }\end{array}$ & $\begin{array}{lc}\text { Laba diukur dengan } \\
\text { indikator } & \text { terpenuhinya } \\
\text { kebutuhan } & \text { produksi dan } \\
\text { pribadi } & \end{array}$ \\
\hline 3. & Butik Rinta Uncha & $\begin{array}{l}\text { a. a. terdapat pemisahan } \\
\text { keuangan entitas bisnis } \\
\text { dan pribadi. } \\
\text { b. b. pencatatan transaksi } \\
\text { hanya berupa pembelian } \\
\text { dan penjualan barang } \\
\text { dagangan. } \\
\text { c. c. sudah menerapkan } \\
\text { konsep harga perolehan. } \\
\text { d. d. hanya menyusun } \\
\text { laporan } \quad \text { keuangan } \\
\text { laba-rugi secara sederhana } \\
\text { dan tanpa biaya periodik }\end{array}$ & $\begin{array}{l}\text { Laba diukur sebesar selisih } \\
\text { harga jual dan harga } \\
\text { perolehan barang dagangan }\end{array}$ \\
\hline
\end{tabular}




\begin{tabular}{|c|c|c|c|}
\hline 4. & Sumber Hasil & $\begin{array}{llr}\text { a. } & \text { a. pencatatan hanya } \\
& \text { dilakukan pada transaksi } \\
\text { pembelian bahan dan biaya } \\
\text { produksi saja. } \\
\text { b. b. hanya laporan } \\
\text { laba-rugi saja yang dibuat } \\
\text { secara sederhana sebatas } \\
\text { pengetahuan pemilik usaha }\end{array}$ & $\begin{array}{l}\text { Laba diukur sebesar selisih } \\
\text { penjualan per bulan dan } \\
\text { biaya produksi per bulan }\end{array}$ \\
\hline 5. & $\begin{array}{l}\text { Retno Bakul Buah } \\
\text { Pamekasan }\end{array}$ & $\begin{array}{l}\text { a. a. pencatatan transaksi } \\
\text { hanya berupa pembelian } \\
\text { buah (bahan), produksi } \\
\text { dan penjualan. } \\
\text { b. b. hanya menyusun } \\
\text { laporan laba-rugi secara } \\
\text { sederhana }\end{array}$ & $\begin{array}{l}\text { Laba diukur dengan cara } \\
\text { menghitung masing-masing } \\
\text { selisih penjualan dan } \\
\text { pembelian buah; selisih } \\
\text { penjualan olahan buah } \\
\text { (salad dan minuman) } \\
\text { dengan biaya produksi }\end{array}$ \\
\hline 6. & Onk Konveksi dan Bordir & $\begin{array}{l}\text { a. a. terdapat pemisahan } \\
\text { fungsi dan tugas } \\
\text { b. b. pencatatan } \\
\text { kompleks } \\
\text { c. c. transaksi yang dicatat } \\
\text { berupa pembelian bahan } \\
\text { baku dan penolong; kinerja } \\
\text { karyawan dan biaya } \\
\text { overhead. } \\
\text { d. h. hanya meyusun } \\
\text { laporan laba-rugi secara } \\
\text { sederhana }\end{array}$ & $\begin{array}{l}\text { Laba diukur sebesar selisih } \\
\text { penjualan dikurangi biaya } \\
\text { produksi tanpa dikurangi } \\
\text { biaya periodik. }\end{array}$ \\
\hline 7. & Green Juice & $\begin{array}{l}\text { a. a. pencatatan transaksi } \\
\text { masih dilakukan secara } \\
\text { manual dan sederhana } \\
\text { berupa } \\
\text { pembelian bahan baku dan } \\
\text { penolong; penjualan per } \\
\text { hari; serta pendapatan } \\
\text { bersih per hari } \\
\end{array}$ & $\begin{array}{l}\text { Laba diukur sebesar selisih } \\
\text { jumlah pendapatan bersih } \\
\text { dalam satu bulan dengan } \\
\text { biaya periodik di waktu } \\
\text { yang sama. }\end{array}$ \\
\hline 8. & $\begin{array}{l}\text { Hamidah Fahas/ Mida } \\
\text { Busana }\end{array}$ & $\begin{array}{l}\text { a. pencatatan transaksi } \\
\text { hanya berupa pembelian } \\
\text { bahan, produksi dan } \\
\text { penjualan }\end{array}$ & $\begin{array}{l}\text { Laba diukur sebesar } \\
\text { persentase tertentu dari } \\
\text { omset kemudian dikurangi } \\
\text { dengan biaya produksi. }\end{array}$ \\
\hline 9. & $\begin{array}{l}\text { Batik Imada/ Rumah Batik } \\
\text { Imada }\end{array}$ & $\begin{array}{l}\text { a. a. pencatatan hanya } \\
\text { berupa } \\
\text { pembelian dan penjualan } \\
\text { batik serta produksi baju } \\
\text { batik. } \\
\text { b. b. pemisahan pencatatan } \\
\text { penjualan secara online } \\
\text { dan offline. }\end{array}$ & $\begin{array}{l}\text { Laba diukur sebesar } \\
\text { persentase tertentu dari } \\
\text { omset kemudian dikurangi } \\
\text { dengan biaya produksi. }\end{array}$ \\
\hline 10. & Teri Crispy Almund & $\begin{array}{l}\text { a. a. transaksi yang dicatat } \\
\text { hanya berupa pembelian } \\
\text { bahan, pelengkap dan } \\
\text { penolong; biaya produksi } \\
\text { dan penjualan. }\end{array}$ & $\begin{array}{l}\text { Laba diukur sebesar selisih } \\
\text { penjualan dan harga pokok } \\
\text { produksi tanpa adanya } \\
\text { biaya periodik. }\end{array}$ \\
\hline
\end{tabular}


Berdasarkan hasil penelitian di atas diketahui bahwa praktik akuntansi bervariatif dan masih dilakukan secara sederhana sebatas pengetahuan para pelaku UMKM bahkan ada beberapa yang tidak melakukan pencatatan transaksi. Praktik akuntansi yang dilakukan oleh para pelaku UMKM masih belum mengacu pada Standar Akuntansi Keuangan Entitas Mikro Kecil Menengah (SAK EMKM) karena kurangnya pengetahuan para pelaku UMKM terhadap akuntansi dan SAK EMKM. Pencatatan transaksi dan pelaporan keuangan dilakukan secara sederhana tanpa memperhatikan kerangka dasar konseptual akuntansi meskipun transaksi penjualan dilakukan secara online. Penjualan secara online yang dilakukan UMKM di Kabupaten Pamekasan belum diikuti dengan sistem pencatatan transaksi secara online bahkan sebagian besar pengendalian manajemen pun masih terpusat pada pemilik karena pada umumnya usaha UMKM ini merupakan usaha keluarga. Praktik akuntansi yang sederhana menyebabkan pengukuran laba yang sederhana pula. Sebagian besar laba diukur sebesar selisih penjualan dan biaya produksi/ kulakan, ada beberapa yang menggunakan estimasi dan ada beberapa yang berdasarkan persentase tertentu dari omset dan ada laba yang diukur berdasarkan kemampuan memenuhi kebutuhan pribadi dan produksi. Jika mengacu pada konsep laba menurut Fisher dan Bendfrod, konsep laba yang digunakan oleh UMKM online di Kabupaten Pamekasan termasuk dalam physic income dan money income di mana disebut mendapatkan laba ketika dari hasil usaha yang ada dapat memenuhi kebutuhan pribadi (hidupnya) dan produksinya serta adanya kenaikan nilai moneter dari sumber dayanya.

Praktik akuntansi yang sesuai dengan SAK EMKM adalah meliputi semua pencatatan transaksi yang dapat mencerminkan posisi keuangan dan kinerja usaha UMKM. Pencatatan transaksi yang dapat mencerminkan posisi keuangan berupa pecatatan transaksi mengenai kas, piutang, persediaan, aset tetap, utang dan ekuitas (modal). Sementara itu, pencatatan transaksi yang dapat mencerminkan kinerja usaha UMKM meliputi pencatatan transaksi pendapatan, beban keuangan (baik periodik atau tidak) dan beban pajak.

Mengacu pada SAK EMKM, laba diukur sebesar selisih pengahasilan (pendapatan dan keuntungan dari pelepasan aset tetap) dengan beban yang terjadi dalam periode yang sama. Pendapatan yang dimaksud merupakan penghasilan yang timbul dari operasional normal entitas UMKM. Sementara itu, beban yang terjadi dalam periode yang sama dengan terjadinya penghasilan meliputi harga pokok penjualan/ produksi, upah dan penyusutan. Umumnya, UMKM di Kabupaten Pamekasan tidak pernah menyusun laporan posisi keuangan sehingga tidak pernah melakukan penyusutan terhadap aset tetap sehingga laba hanya diukur secara sederhana sebatas pengetahuan para pelaku UMKM. Namun demikian dari sepuluh sampel yang ada dalam penelitian ini ada satu sampel yang telah mempraktikkan matching concept yaitu konsep menandingkan pendapatan dan beban pada periode yang sama serta ada satu sampel yang telah mengenal dan mempraktikkan konsep harga perolehan dalam menentukan harga jualnya.

\section{Kesimpulan}

Berdasarkan hasil penelitian di atas dapat ditarik beberapa kesimpulan, yaitu pencatatan masih dilakukan secara sederhana dan manual meskipun penjualan telah dilakukan secara online. Praktik akuntansi yang dilakukan oleh para pelaku UMKM bervariatif dan sebatas pengetahuan para pelaku UMKM bahkan ada beberapa yang tidak melakukan pencatatan transaksi. Praktik akuntansi yang dilakukan oleh para pelaku UMKM masih belum mengacu pada Standar Akuntansi Keuangan Entitas Mikro Kecil Menengah (SAK EMKM) karena kurangnya pengetahuan para pelaku UMKM terhadap akuntansi dan SAK EMKM. Praktik akuntansi yang dilakukan secara sederhana oleh para pelaku UMKM di 
Kabupaten Pamekasan menyebabkan pengukuran laba yang sederhana dan juga bervariasi sebatas pengetahuan pelaku UMKM dan belum mengacu pada SAK EMKM. Sebagian besar laba diukur sebesar selisih penjualan dan biaya produksi/ kulakan, ada beberapa yang menggunakan estimasi dan ada beberapa yang berdasarkan persentase tertentu dari omset dan ada laba yang diukur berdasarkan kemampuan memenuhi kebutuhan pribadi dan produksi.

\section{Implikasi}

Penelitian ini memiliki beberapa implikasi baik bagi penulis, pembaca dan Pelaku UMKM yaitu penulis dapat memperoleh dan menambah pengetahuan tentang praktik akuntansi dan pengukuran laba UMKM online di Kabupaten Pamekasan serta memberikan sumbangan pemikiran dalam memperkaya konsep dalam penulisan berikutnya; pembaca dapat mengetahui hasil penelitian serta keterbatasan dalam penelitian ini dan sebagai sumber referensi terbaru dari temuan penelitian ini; bagi pelaku UMKM, sebagai sarana informasi pelaksanaan praktik akuntansi dan pengukuran laba yang sesuai dengan standar SAK EMKM sehingga dapat meningkatkan pelaksanaan praktik akuntansi dan pengukuran laba UMKM di Kabupaten Pamekasan. Pengukuran laba yang tidak sesuai dengan SAK EMKM tidak dapat diajdikan acuan dasar pengambilan keputusan bagi penggunanya sehingga dibutuhkan pengukuran laba yang sesuai dengan SAK EMKM.

\section{Keterbatasan}

Selain memiliki implikasi, penelitian ini juga memiliki keterbatasan yaitu dari jumlah populasi UMKM yang ada di Kabupaten Pamekasan hanya digunakan 10 UMKM online yang dijadikan sampel. Penelitian ini juga perlu dilakukan dengan pendekatan kuantitatif untuk diuji lebih lanjut.

\section{Daftar Pustaka}

Aliyah, Siti. 2014. Makna Pajak Dan Implikasinya Dalam Bingkai Perspektif Wajib Pajak Umkm (Studi Interpretatif Pada Wajib Pajak UMKM Di Kabupaten Jepara). Jurnal Dinamika Ekonomi \& Bisnis 11(1): 82

Andasari, Pipit Rosita dan Justita Dura. 2018. Implementasi Pencatatan Keuangan Pada Usaha Kecil dan Menengah (Studi Pada Sentra Industri Kripik Tempe Sanan di Kota Malang). Jurnal JIBEKA 12(1):59-64.

Andhika, Yohanes Hendri dan Theresa Woro Damayanti. 2017. Niat Melakukan Pencatatan Akuntansi Pada Usaha Kecil Menengah: Pengetahuan Akunansi ataukah herding. Jurnal Ekonomi dan Bisnis 20(2):331-46.

Anthony, Robert N. dan Govindarajan Vijay. 2009. Sistem Pengendalian Manajemen. Jakarta: Selemba Empat

Baridwan, Zaki. 2004. Intermediate Accounting. 8 ed. Yogyakarta: BPFE.

Diniyanti, Dewi dan Agusrinal. 2014. Perencanaan Strategi Pemasaran Pada Produk Ayaman Pandan..Jurnal sains 11(2):175-84.

Ghozali, Imam dan Anis Chariri. 2014. Teori Akuntansi International Financial Reporting System (IFRS). 4 ed. Semarang: Universitas Diponegoro.

Harahap, Sofyan Syafri. 2015. Teori Akuntansi. Depok: PT. Rajagrafindo Persada.

Hutagaol, Renaldo Martin Novinto. 2012. Penerapan Akuntansi Pada Usaha Kecil Menengah. Jurnal Ilmiah Mahasiswa Akuntansi 1(2):57-62.

Jusup, Al. Haryono. 2011. Dasar-dasar Akuntansi. 7 ed. Yogyakarta: Sekolah Tinggi Ilmu Ekonomi YKPN. 
Karimoellah. 2019. "Jumlah Penduduk Kabupaten Pamekasan Tahun 2018." Diambil 27 Desember

(http://karimoellah.net/jumlah-penduduk-kabupaten-pamekasan-tahun-2018/).

Keuangan, Dewan Standar Akuntansi. 2016. Standar Akuntansi Keuangan Entitas Mikro, Kecil dan Menengah. Eksposure Draft. Ikatan Akuntansi Indonesia.

Santoyo, Danang. 2013. Metode Penelitian Akuntansi. Bandung: Refika Aditama.

Savitri, Rosita Vega dan Saifudin. 117M. Pencatatan Akuntansi Pada Usaha Mikro dan Menengah (Studi Pada UMKM MR.Pelangi Semarang). Jurnal Manajemen Bisnis dan Inovasi 5(2):Juli 2018.

Suryani, Ita. 2014. "Pemanfaatan Media Sosial Sebagai Media Pemasaran Produk dan Potens Indonesia Dalam Upaya Mendukung ASEAN Community 2015. ( Studi Social Media Marketing Pada Twitter Kemenparekfar RI dan Facebook Disparbud Provinsi Jawa Barat)." Jurnal Komunikasi 8(2):123-38.

Syakur, Ahmad Syafi'i. 2015. Intermediate Accounting Dalam Perspektif Lebih Luas. Revisi. Jakarta: AV Publisher.

Watie, Errika Dwi Sety. 2011. Komunikasi dan Media Sosial (Communication and Social Media). The Messenger 3(1):69-75.

Wibowo Dimas Hendika, Arifin Zainul, dan Sunarti. 2015. Analisis Strategi Pemasaran Untuk Meningkatkan Daya Saing Umkm (Studi Pada Batik Diajeng Solo). Jurnal Administrasi Bisnis 29(1): 60 